\title{
Deslocamentos etnográficos: religião, raça e poder em Moçambique
}

Lívia Reis ${ }^{1}$

Universidade Federal do Rio de Janeiro

Resumo: Tendo como base o trabalho de campo realizado junto a crentes da Igreja Universal do Reino de Deus (IURD) em Maputo, capital de Moçambique, este artigo reflete sobre alguns deslocamentos impostos ao pesquisador no decorrer do fazer etnográfico. Partindo de três diferentes etapas da pesquisa, o trabalho de campo, a construção do objeto e o tempo da escrita, demonstro como a experiência de aprendizado com jovens crentes - comumente percebidos a partir de uma alteridade repugnante - revelou um jogo de ambivalências e situações inesperadas que colocaram em xeque minha identidade negra e, consequentemente, a percepção das relações de poder entre mim e eles. Demonstro, ao final, o rendimento analítico trazido pela opção de apreender a "religião" em movimento, a importância do distanciamento do campo para que eu pudesse perceber os diferentes sentidos dos deslocamentos e os efeitos epistemológicos dessas constantes negociações para a produção antropológica.

Palavras-chave: Igreja Universal do Reino de Deus; etnografia; identidades; poder; Moçambique. 


\title{
Ethnographic displacement: religion, race and power in Mozambique
}

\begin{abstract}
Based on the fieldwork carried out with believers from the Universal Church of the Kingdom of God (IURD) in Maputo, capital of Mozambique, this article reflects on some displacements imposed on the researcher in the course of ethnographic work. Starting from three different stages of research, the fieldwork, the construction of the object and the time of writing, I demonstrate how the learning experience with young believers - commonly perceived from a repugnant otherness - revealed a game of ambivalences and unexpected situations that put in check my black identity and, consequently, the perception of the power relations between me and them. In the end, I demonstrate the analytical performance brought by the option to apprehend "religion" in movement, the importance of distance from the field so that I could perceive the different meanings of displacements and the epistemological effects of these constant negotiations for anthropological production.
\end{abstract}

Keywords: Universal Church of the Kingdom of God; ethnography; identities; power; Mozambique.

\section{Cambios etnográficos: religión, raza y poder en Mozambique}

\begin{abstract}
Resumen: Basado en el trabajo de campo realizado con creyentes de la Iglesia Universal del Reino de Dios (IURD) en Maputo, capital de Mozambique, este artículo reflexiona sobre algunos desplazamientos impuestos al investigador en el curso del trabajo etnográfico. A partir de tres etapas diferentes de la investigación, el trabajo de campo, la construcción del objeto y el tiempo de escritura, demuestro cómo la experiencia de aprendizaje con los jóvenes creyentes, comúnmente percibida por una repugnante otredad, reveló un juego de ambivalencias y situaciones inesperadas. eso puso en jaque mi identidad negra y, en consecuencia, la percepción de las relaciones de poder entre ellos y yo. Al final, demuestro el desempeño analítico que brinda la opción de aprehender a la "religión" en movimiento, la importancia de la distancia del campo para poder percibir los diferentes significados de los desplazamientos y los efectos epistemológicos de estas negociaciones constantes para la producción antropológica.
\end{abstract}

Palabras clave: Iglesia Universal del Reino de Dios; etnografía; identidades; poder; Mozambique. 
$\mathrm{E}$ ra novembro de 2014 e já fazia alguns meses que eu havia começado o trabalho de campo com jovens crentes da Igreja Universal do Reino de Deus (IURD) em Maputo, capital de Moçambique, acompanhando cotidianamente suas atividades dentro e fora da igreja. Naquele domingo, ao final de um culto, me dirigi com algumas amigas até o lado de fora do Cenáculo Maior, sede da IURD na cidade, para encontrar o restante do grupo. Como de praxe, os jovens ligados à Força Jovem Universal (FJU) se reuniam ali para uma atividade que se repetia todos os dias após o encerramento das atividades ordinárias na igreja. A "concentração", uma categoria nativa, pode ser definida como uma reunião de membros interessados em se informar sobre as atividades do grupo jovem por meio dos recados transmitidos pelas lideranças após os cultos e encontros 3 . Durante a semana, ela costumava acontecer no hall de entrada do Cenáculo, mas, aos domingos, devido ao trânsito maior de pessoas, era realizada na calçada em frente à igreja, isto é, na rua. Depois que um número mínimo de jovens se reunia, um obreiro, quase sempre o obreiro líder da FJU, posicionava-se no centro do círculo de pessoas para transmitir comunicados importantes ou conselhos mais gerais aos membros do grupo e, ao final, realizava uma oração. Só depois da concentração é que as atividades do grupo eram consideradas oficialmente encerradas e os jovens liberados para voltar para casa4.

Neste dia, no entanto, um mistério pairava no ar. Havia um burburinho sobre uma possível reunião no dia seguinte com o Bispo Jean5, líder da IURD no país, e cuja participação seria restrita a trezentos jovens. Citando a passagem bíblica de Mateus 22: 14, na qual Jesus afirma que "muitos são chamados, mas poucos escolhidos", o obreiro enfatizou que os jovens selecionados deveriam comparecer à reunião trajando a roupa mais bonita de seus armários, pois encontrariam um representante de Deus. Ao perceber que o conselho gerou expectativa entre os jovens, não me senti confortável em participar e, eventualmente, "roubar" o lugar de um fiel que quisesse ir ao evento, motivo pelo qual me afastei do grupo para comprar um lanche. Enquanto caminhava, notei que o obreiro começara a escolher os fiéis, apontando individualmente os selecionados. Eu estava distraída comprando salgadinhos quando Maria, uma amiga da igreja e importante interlocutora, veio até mim para informar que o obreiro lhe pedira para avisar que "aquela clarinha" - no caso, eu - havia sido escolhida.

Minha primeira reação foi perguntar à Maria se deveria ou não aceitar o convite para a reunião que, descobri no dia seguinte, introduziria a temática da Fogueira Santa, uma importante corrente anual realizada na IURD ${ }^{6}$ que teria início dali a uns dias. No entanto, e é para isso que quero chamar atenção ao descrever toda a cena, a forma como o obreiro se referiu a mim para Maria impôs um novo conjunto de problemas ao meu trabalho de campo. Em primeiro lugar, constatei que as lideranças sabiam que eu existia e que, apesar de me considerarem diferente das outras pessoas, mais clarinha, jamais me interpelaram para saber da

${ }^{2}$ Em itálico estão as palavras estrangeiras. Entre aspas estão as categorias "nativas" e citações textuais com menos de três linhas.

3 Notei que outros grupos temáticos da IURD também realizavam concentrações ao final das reuniões.

4 Sobre as atividades da FJU em Maputo, cf. Reis, 2018.

5 Os nomes dos fiéis são fictícios, mas optei por manter o nome das lideranças.

${ }^{6}$ Cf. Teixeira, 2016; Reis, 2018. 
minha vida ou o que eu fazia ali, algo comum dentro dos grupos etários ou temáticos da IURD. Como explicarei mais adiante, optei por não me apresentar à hierarquia da igreja após avaliar inicialmente que isso poderia colocar meu trabalho e a mim mesma em risco. Com relação a essa reunião, especificamente, minha preocupação estava relacionada exclusivamente com a restrição ao número de pessoas, mas fui convencida por Maria sob o argumento de que, se o obreiro me escolhera, era porque eu deveria ir.

Como explicitei na tese, meus interlocutores sabiam que eu não era religiosa, mas nunca deixaram de acreditar que eu pudesse me converter. Por isso, qualquer oportunidade era vista como uma chance real de que eu fosse tocada pelo Espírito Santo. Para eles, quanto mais eu frequentasse a igreja, maiores as chances de conversão e, como crentes, era seu papel cuidar para que isso acontecesse. De minha parte, jamais considerei possível produzir um distanciamento que tomasse como dado a impossibilidade de uma vivência espiritual junto aos crentes. Nossa relação era atravessada por essa ambivalência e isso nunca foi um problema, ao menos para mim.

Decidi comparecer à reunião, afinal. Informei meu nome e telefone a uma das obreiras encarregadas de organizar a lista de convidados e passei o caminho de volta para casa revisitando memórias em torno do processo lento e gradual de construção da minha negritude no Brasil. O objetivo, obviamente, era entender por que eu havia me chocado tanto por ter sido considerada "clarinha", assim, no diminutivo, o segundo e principal problema colocado por essa situação etnográfica. Lembrei-me que, durante boa parte da minha vida, fui uma negra de classe média, moreninha ou pretinha, dependendo do contexto, que circulava apenas em ambientes brancos e que sempre tentou se blindar do racismo seguindo padrões estéticos e relacionais brancos, mesmo que de forma inconsciente. Alisei o cabelo por anos, convivia e me relacionava afetivamente com pessoas brancas, estudei toda a vida em colégios particulares onde era uma das únicas negras e fiz minha primeira graduação numa faculdade pública de Direito antes da política de cotas, ou seja, majoritariamente branca.

Apesar das minhas tentativas de branqueamento, evidentemente eu era lida socialmente como uma mulher negra e a busca por entender como lidar com isso me levou para as Ciências Sociais. Ali, meus incômodos encontraram sentido e, melhor, uma explicação. Por isso mesmo, foi desconcertante descobrir naquele dia que, em Moçambique, eu não era negra. Não da forma como eu entendia minha negritude, constituída por minha cor de pele e atravessada por representações sociais, desigualdades e discriminações raciais, como aprendi com o debate interseccional (RIOS, 2019), mas que estavam relacionadas ao contexto sóciohistórico brasileiro. Em Moçambique, meu fenótipo me fazia "mulata" para meus amigos de classe média-alta e descendentes de portugueses e branca ou clara para pessoas negras. No entanto, minha condição econômica acima da média moçambicana - embora bolsista de doutorado - e, ainda, de estrangeira, um "mulungo"7, também ajudava a compor a percepção racial e social que os crentes formavam de mim. Independente de ser mulata, clarinha ou branca, o fato é que eu havia entendido finalmente que não era negra como os negros de lá ${ }^{8}$.

7 No Brasil, mulungo(a) seria o equivalente a gringo(a), um nome pejorativo dado aos estrangeiros.

${ }^{8}$ Sobre as complexas relações raciais em Moçambique, cf. Thomaz (2006). 


\section{Branca, estrangeira e brasileira: costurando caminhos a partir de identidades móveis}

Ao longo da minha tese, relato como a minha própria crença se relacionou com a crença dos meus "outros" durante o trabalho de campo e como a experiência com crentes podia ajudar a pensar o fazer antropológico. Eu fui a campo preparada para isso, mas, por ingenuidade ou inexperiência, a questão racial me pegou despreparada. A despeito das relações de poder que permeiam o trabalho de campo e das assimetrias nas relações estabelecidas entre antropólogos e seus "interlocutores", eu pensava que poderia estabelecer um vínculo mais horizontal com as pessoas ao meu redor, afinal, eu era uma mulher negra fazendo trabalho de campo com pessoas negras. Naquele dia, entretanto, me dei conta de que se tratava apenas da ilusão de alguém que não esteve atenta às pistas sobre essa questão que já haviam aparecido em outros momentos da vida em Maputo, nas vezes em que me dava ao luxo de esquecer que era uma antropóloga em permanente trabalho de campo.

Transportei-me, então, para o dia em que cheguei a Maputo. Meu primeiro contato com a empregada da casa onde aluguei um quarto foi impactante: embora estivesse muito feliz, em suas palavras, por "trabalhar para uma brasileira", ela não me olhava nos olhos, falava com a cabeça baixa, não se sentava à mesa para almoçar comigo por mais que eu pedisse e nem mesmo compartilhava o banheiro da casa. Depois, lembrei-me de nossa convivência diária e de como Adélia me ensinou em seu português quase incompreensível que, para ela, eu era indubitavelmente branca. Além disso, costumava reclamar dos mulatos moçambicanos com quem convivia, afirmando que eles se achavam melhores que os negros. Seja por ato falho ou pura negação, em momento algum pensei as questões de Adélia à luz da minha identidade de pesquisadora até o fatídico dia em que fui indiretamente interpelada pela fala do obreiro.

Para além disso, eu era brasileira, não uma estrangeira qualquer. Nos meus primeiros minutos em solo moçambicano, ainda antes de chegar em casa, a jovem que me vendeu um chip de celular na rua - e que, coincidentemente, pertencia a uma das tribos 9 que pesquisei na Força Jovem - rapidamente mudou o sotaque ao perceber minha nacionalidade e começou a falar comigo "assim como falavam na novela" - revelou-me. De maneira geral, os moçambicanos têm uma relação de admiração e respeito com o Brasil. Segundo Thomaz (2001: 37), as imagens do Brasil como um modelo de integração racial que deu certo foram apropriadas desde o período colonial pelos atores que participaram do processo de libertação do país, além de existir uma intensa aproximação no terreno cultural. Com o passar do tempo, essa aproximação se intensificou na medida em que músicas, novelas, roupas, cosméticos, políticas públicas para fortalecimento das relações sulsul e, não sem críticas, igrejas e empresas passaram a compor o conjunto de referências brasileiras facilmente encontradas em terras moçambicanas. Para completar, eu vinha do lugar onde a IURD surgiu, e, ainda que, curiosamente, a maioria dos fiéis não soubesse da origem brasileira da igreja que frequentavam, sabiam que o Templo de Salomão, destino turístico dos sonhos de muitos deles, estava localizado no Brasil. Diante desse cenário - ainda que não sem desconfiança - a maioria dos fiéis com quem me relacionei expressava uma postura de admiração para comigo.

9 A Força Jovem Universal era dividida internamente para facilitar a organização do grupo. Estes subgrupos eram chama- 
No entanto, ao contrário do que se possa imaginar num primeiro momento, toda essa conjuntura serviu para acentuar ainda mais o medo que eu tinha de que o campo "desse errado", além de me deixar numa posição profundamente desconfortável. Eu simplesmente não sabia ser a pessoa que diziam que eu era e foi muito difícil me adaptar a esse novo registro de existência. De todo modo, enfrentar essa situação fez com que eu me desse conta de que a assimetria ali existente era indefinidamente maior do que eu pensava que seria, como já alertava Clifford ao afirmar que o trabalho etnográfico "coloca em cena relações de poder". No entanto, continua o autor, "sua função nessas relações é complexa, por vezes ambivalente, e potencialmente contra-hegemônica" (CLIFFORD, 2016: 41) e, embora eu não soubesse como estabeleceria uma relação de troca sem me aproveitar desse lugar de poder, o fato é que ele existia e eu precisei aprender a lidar com isso.

Como bem lembrado por Ortner (2006: 63), "as histórias da Antropologia e do colonialismo por muito tempo andaram juntas, e, à luz dessas histórias as próprias práticas da Antropologia eram repensadas", motivo pelo qual passei a ocupar boa parte do meu tempo tentando encontrar uma maneira menos caricatural de ser antropóloga. Inicialmente, comecei a aplicar algumas regras que eu julgava corretas para resolver determinadas assimetrias: dividia a conta de igual para igual com as meninas sempre que comíamos - embora vez ou outra eu tivesse que convidar as que estavam sem dinheiro algum - e estabelecia uma relação de troca que, a meu ver, seria a mais justa. Se eu oferecesse os ingredientes do almoço, elas tinham que cozinhar algum dos pratos e assim por diante. Embora elas tenham, inclusive, pagado lanches ou passagens de "chapa" ${ }^{10}$ para mim nas vezes em que fui sem dinheiro ao Cenáculo, isso não impediu que me pedissem dinheiro emprestado sem que nunca pagassem de volta - ainda que eu tenha cobrado -, que me pedissem Bíblias ou livros da IURD de presente ou que uma das minhas amigas me roubasse uma grande quantia em dinheiro, cerca de $\mathrm{R} \$ 1.000,00$. Ficou evidente, ao final, que eu não resolveria assimetria alguma dessa forma.

Passada a frustração inicial, me dei conta de que a noção de "troca justa" era apenas minha, não delas, e acabei pagando um preço alto por não ter compreendido a tempo os códigos por elas emitidos - os ditos e os não ditos. Por mais que mantivéssemos uma relação amistosa, a maioria delas vivia em situação precária, dividindo casa com muitos membros da família - escutei casos de quatro ou cinco pessoas por cômodo - e eu concluí que, naquele contexto, eu deveria ter oferecido uma compensação em dinheiro pela ajuda na pesquisa que eu efetivamente recebia. Maria, especificamente, atuava como uma assistente de pesquisa das mais dedicadas: guardava folhetos e matérias de jornal que me interessavam, ligava para avisar sobre alguma reportagem na televisão, aconselhava sobre como me comportar ou não me comportar na igreja. Se, na minha concepção, eu retribuía a ajuda delas proporcionando momentos de lazer, almoços ou jantares, não era isso, definitivamente, o que elas precisavam. Tratar o dinheiro como um tabu, neste caso, revelava mais sobre meus valores morais e éticos do que sobre as relações entre nós estabelecidas, o que me levou a questionar mais uma vez as condições de produção dos meus dados. Se, inevitavelmente, não é possível prever as situações que exigirão uma mudança de postura no decorrer do trabalho etnográfico - sobretudo quando ele é atravessado por relações de poder que jamais serão apagadas, mas negociadas - é necessário que estejamos preparados para reconhecer sua contingência e abertos para traçar caminhos alternativos. 


\section{O "outro repugnante" e o trabalho antropológico: alternativas possíveis}

A percepção quase tardia da forma como os meus "outros" me percebiam em campo, portanto, foi fundamental para os rumos posteriores do meu trabalho. Em primeiro lugar, porque colocou em jogo minha identidade e as relações de poder entre mim e eles, e não somente entre fiéis, igreja e Estado - plano inicial de minha pesquisa. Depois, porque esse jogo foi atravessado por outra questão igualmente importante e intrinsecamente conectada às duas primeiras, isto é, o fazer etnográfico junto àqueles comumente percebidos por nossos pares antropólogos a partir de uma alteridade repugnante, nos termos propostos por Harding (1990).

Em seu trabalho sobre as origens do "fundamentalismo", a autora nos mostra que a categoria surge como contraponto à ideia de modernidade e deve ser pensada a partir dessa perspectiva. Com base em uma pesquisa documental, Harding propõe uma genealogia que tem como ponto de partida um episódio de consagração e visibilização do termo - uma disputa judicial sobre o ensino do criacionismo nas escolas que tem como uma das partes "fundamentalistas cristãos" - e não a origem etimológica da palavra, para demonstrar que o tratamento dado ao grupo está assentado na oposição entre modernidade e atraso. Se, por um lado, o pensamento antropológico foi capaz de produzir "outros" culturais legítimos, em geral minorias étnicas e identitárias, o fundamentalista é percebido como um outro hipoteticamente antimoderno e, portanto, repugnante. Como saída possível, a autora sugere que os "fundamentalistas" sejam tratados a partir de um quadro que não reproduza uma oposição totalizante entre nós e eles, pois negar a marginalidade desses grupos significaria negar sua própria existência. Já Coleman (2018), que retoma magistralmente a ideia de Harding para aprofundá-la, propõe que os pesquisadores do "cristianismo conservador" se apeguem às "zonas fronteiriças" onde as ambivalências aparecem, prestem atenção à temporalidade de enquadramentos éticos (nosso e deles) e considerem a experiência pentecostal como fragmentada, e, consequentemente, permeada também pelo lúdico e pelo irônico.

À luz desses estudos, concluí que um trabalho de campo que focasse na religiosidade tal como vivida por membros-engajados da IURD, não por membrosflutuantes, poderia se apresentar como solução possível para todas as minhas inquietações. De acordo com Orsi (2010), a "religião vivida" ${ }^{11}$, conceito que escolhi para guiar minha observação, só tem significado em relação com outras formas culturais, experiências de vida e circunstâncias nas quais está inserida, de modo que só pode ser compreendida situacionalmente. Já Hartel (2006), ao apontar as lacunas de trabalhos que adotaram este conceito como perspectiva teórica, ressalta que a maioria dos autores reconhece a importância da performatividade como ferramenta conceitual, mas subestima a importância da cultura material e visual para examinar como as pessoas reais fazem e veem suas práticas religiosas em determinadas circunstâncias. Assim, tanto o trabalho de Hartel (2006) sobre o processo de santificação do Padre Backer numa diocese norte-americana, quanto às dinâmicas em torno da Madonna da 115th Street descritas por Orsi (2010), nos mostram como o mundo material "aparece não apenas como um cenário inerte para as práticas culturais, mas, ao contrário, constitui seu meio essencial" (idem: xxxix, tradução minha).

${ }^{11}$ Ver Hall, 1997; Orsi, 2010 [1985]; Hartel, 2006. 
A meu ver, acompanhar as trajetórias dos membros, prestando atenção ao que faziam, com o que faziam e como faziam, me ajudaria a entender as negociações feitas pelos fiéis ao transitar por esse mundo fragmentado a partir de seu pertencimento religioso. Ao fazer essa opção, contraponho-me às análises feitas no Brasil que classificam a IURD como igreja de "serviço" (PIERUCCI, 1998; MARIANO, 2005; CAMPOS, 1997), bem como à análise realizada por van Wyk (2014) sobre a IURD na África do Sul, que chama atenção para a total ausência de laços sociais entre membros da IURD em Durban e até mesmo à análise de Kamp (2016), que destaca a fraca sociabilidade engendrada pela IURD em Maputo. Considerando que grande parte das pesquisas sobre evangélicos é centrada nos discursos e práticas institucionais e que, embora importante, esse tipo de análise tende a reduzir o lugar e a capacidade de agenciamento dos fiéis, fazer do cotidiano dos membros o centro da observação ajudaria a entender esse "outro" em toda a sua complexidade. Para isso, eu deveria levar a sério as categorias nativas, ações, reações, dúvidas, entrega e questionamentos de meus interlocutores, o que incluía, descobri em campo, considerar a forma como eu era percebida por eles.

Toda essa reflexão me ensinou, no fim das contas, que o trabalho de campo não é feito apenas de escolhas metodológicas, sempre arbitrárias e redutoras, mas também de contingências que nos obrigam a repensar nosso próprio lugar durante o campo. Ter minha identidade e, consequentemente, meu lugar de poder tão bruscamente deslocados reverberou diretamente na forma como passei a refletir sobre as relações construídas entre mim e meus interlocutores, no conjunto de reflexões a partir das quais construí meu objeto e, finalmente, no conhecimento antropológico produzido e textualizado posteriormente. É sobre estas três etapas que passo a falar a partir de agora.

\section{Entrando em campo}

Antes de narrar os outros deslocamentos realizados ao longo do campo, fazse necessário descrever rapidamente a forma como me inseri nele. Morei em Maputo entre agosto de 2014 e fevereiro de 2015, período em que estive vinculada como pesquisadora visitante no Centro de Estudos Africanos da Universidade Eduardo Mondlane (UEM). Ao longo dos seis meses, realizei observação participante nos cultos, frequentei reuniões de grupo temáticos, festas, ações assistenciais e de evangelização fora da igreja, além de acompanhar trajetórias de diferentes fiéis, todas mulheres, em seu cotidiano dentro e fora da igreja. É possível afirmar que fui a todas as dinâmicas oferecidas aos fiéis pela hierarquia da igreja neste período e frequentei o Cenáculo em todos os dias da semana, ainda que não na mesma semana.

De fato, seria arrogante da minha parte estabelecer qualquer comparação com a participação observante realizada por Wacquant nos ringues, quando ele resolveu se tornar um boxeador e dedicar-se integralmente ao projeto a ponto de participar de torneios profissionais, tal como ele fez em Corpo e Alma: notas etnográficas de um aprendiz de boxe (2002). Embora eu não tenha ido ao campo com o objetivo de me tornar crente, logo me convenci de que seria impossível passar por ali sendo uma mera observadora se me dispunha a compartilhar momentos tão intensos com os fiéis. Para o bem e para o mal, assim como aconteceu com Wacquant, meu aprendizado com os crentes passou pelo corpo e fez de mim uma pesquisadora-experimentadora de sensações, mediações, orações e práticas iudianas. 
Como bem colocado por Goldman, é importante reconhecer a etnografia como um devir, isto é, "um movimento através do qual um sujeito sai de sua própria condição por meio de uma relação de afetos que consegue estabelecer com uma condição outra” (2003: 464). O afeto, neste caso, não tem nada a ver com emoções, sentimentos ou empatia, mas com deixar-se afetar pelas mesmas forças que afetam o nativo. Ainda que eu não saiba afirmar se fui ou não afetada pelas mesmas forças que afetavam a eles, no sentido atribuído por Goldman, reconheço que acompanhar cotidianamente a religiosidade iurdiana me afetou de muitas formas. Em geral, eu participava ativamente dos cultos, respondia fisicamente aos estímulos ali experimentados - chorei, me emocionei, tremi, passei mal - e cheguei a ser "assistida" por uma obreira que identificou em mim o espírito da inveja. Mesmo por isso, houve vezes em que precisei ser mais cuidadosa com as expressões corporais, de modo a evitar ser interpelada por obreiros durante eventos cujos detalhes eu considerava importante observar mais atentamente. De todo modo, essas negociações impostas pelo campo são constitutivas da produção antropológica (BLANES, 2006) e não foram raras as vezes em que precisei fazer mudanças de meio de caminho, às vezes mais de uma durante um mesmo evento.

Resolvida a questão sobre a forma como eu viveria o campo, precisei decidir se me identificaria ou não como pesquisadora para as lideranças da igreja. Minha supervisora moçambicana na UEM, Teresa Cruz e Silva, alertou-me sobre os possíveis riscos que envolveriam essa decisão, baseada em sua experiência alguns anos antes. ${ }^{12}$ De acordo com seu relato, ela não pôde continuar o trabalho porque se identificou como pesquisadora. Embora não tenha sido impedida formalmente de ir à igreja, os fiéis deixaram de responder suas perguntas, inviabilizando, assim, a realização da pesquisa. No Brasil, como sabemos, muitos trabalhos produzidos sobre igrejas evangélicas adotam um tom de denúncia ou pejorativo, tema já abordado por Mariz (1995), Giumbelli (2002) e Mariz e Campos, (2011), motivo pelo qual lá, como cá, pesquisadores também são vistos com desconfiança pelas lideranças das grandes igrejas brasileiras.

Como se não bastasse, o tempo escolhido para realização do meu campo coincidiu, propositadamente, com a campanha eleitoral, um período que desde o fim da guerra civil ${ }^{13}$ e do estabelecimento de eleições democráticas costuma ser marcado por conflitos e mortes no país. Tendo em vista que o partido governante, a Frelimo, e a IURD mantêm uma relação de cooperação mútua (FRESTON, 2005; REIS, 2018; 2019), são comuns as acusações de favorecimento entre partido e igreja na mídia, no senso comum e sobretudo entre opositores políticos. Portanto, ser confundida com uma jornalista ou ter as intenções de pesquisa sob escrutínio naquele contexto poderia colocar minha própria integridade física em risco, alerta que me foi dado por um amigo moçambicano assim que desembarquei em Maputo e que eu decidi levar à sério.

Em resumo, a possibilidade de ser impedida de pesquisar a IURD naquele momento existia e esse, definitivamente, não era o meu propósito. Após tentar sem sucesso algumas das estratégias de inserção, optei, depois de uma conversa derradeira com Kamp ${ }^{14}$, por me apresentar como pesquisadora exclusivamente às pessoas cujas trajetórias eu fosse acompanhar. Na prática, isso significou que eu desisti de me apresentar formalmente à hierarquia da igreja a não ser que fosse

\footnotetext{
12 Ver Cruz e Silva, 2003.

13 Após a independência de Moçambique, em 1975, seguiu-se a guerra civil, travada entre a Frelimo e a Renamo, que acentuou ainda mais as desigualdades existentes no país. A nomenclatura da guerra que se seguiu à independência é uma categoria em disputa.

14 Antropóloga holandesa que pesquisou igrejas pentecostais em Maputo e que me prestou fundamental ajuda durante todo o doutorado. Sobre a sua pesquisa e estratégias de inserção em campo, ver Kamp, 2016.
} 
interpelada por eles - o que nunca aconteceu. Como minha análise recairia sobre as práticas cotidianas dos crentes a partir de seu pertencimento à igreja, não sobre a instituição em si, jamais considerei um problema ético frequentar as atividades abertas ao público oferecidas pela IURD. Não se trata, como questiona Nader (1969), de operar com éticas diferentes ao se pesquisar "para cima" e "para baixo". Meus interlocutores, incluindo obreiros com quem me relacionei diretamente, sabiam sobre o trabalho e colaboravam com ele, e eram essas pessoas que me interessava acompanhar. No Brasil, minhas experiências anteriores de pesquisa em megatemplos pentecostais incluíram o diálogo com lideranças, posto que interessadas também em sua atuação político-partidária, mas a experiência moçambicana exigiu que eu levasse em consideração os riscos à minha integridade física e foi esse o cuidado que pesou na decisão de me expor o mínimo possível.

Passados os percalços iniciais, aos poucos estreitei os laços de amizade com algumas fiéis, de modo que elas passaram a frequentar a minha casa e organizar saídas de lazer, como comer pizza ou jogar conversa fora na praia da Costa do Sol. Ainda que tenha conversado com homens e me aproximado do obreiro líder do meu grupo, o campo impôs que eu limitasse minha rede de amizade, e, consequentemente, minha pesquisa, entre mulheres. Na FJU, não era bem visto que homens e mulheres fossem íntimos e não considerei como opção transgredir essa regra. Entretanto, ainda que não pudesse acessar o universo masculino diretamente, eu não deixava de observar como homens e mulheres se relacionavam entre si, ainda que de uma perspectiva mediada pelas fiéis e por meu próprio lugar como pesquisadora mulher, um exemplo claro de como a identidade do pesquisador influencia a construção do objeto.

É evidente, portanto, que minha compreensão do campo possui um recorte de gênero. O conhecimento produzido por nós, antropólogos, é localizado e, mais importante que a busca por uma suposta neutralidade é elucidar esse lugar detalhadamente para o leitor. Nesse sentido, foi essa rede de confiança feminina estabelecida a partir da FJU que deu origem à tese de doutorado que eu escrevi. Estar com elas cotidianamente, sobretudo fora das rede de vigilância da igreja, me ajudou a abordar assuntos que não seriam abordados de outra maneira e produzir dados que me permitiram entender como a religiosidade iurdiana operava no cotidiano, sobretudo fora do templo.

Como a antropologia é uma via de mão dupla, eu também era constantemente interpelada por elas, por vezes até de maneira sarcástica, em relação a temas como casamento e carreira. Elas não entendiam, por exemplo, por que eu tinha deixado um namorado no Rio de Janeiro para ficar tanto tempo distante em Maputo ou, então, porque eu ainda não tinha filhos. Aos risos, alegavam que quando velha eu não seria mais capaz de correr atrás das crianças. A maioria das minhas interlocutoras tinha filhos desde os 18, 20 anos, e este, inclusive, era um tema recorrente nas reuniões de jovens na igreja. $\mathrm{O}$ conceito alargado de prosperidade na IURD, como apontam Scheliga (2010) e Teixeira (2016), inclui o planejamento familiar, de modo que um casal só é orientado a ter filhos depois de adquirir alguma estabilidade financeira, o que não era o caso de nenhuma delas. Na prática, entendi que muitas das fiéis se aproximavam de mim menos porque queriam contribuir com a minha pesquisa e mais porque me se interessavam em saber curiosidades sobre Brasil - como novelas, artistas, produtos de beleza, moda e a vida no Rio de Janeiro - e sobre mim, que estava num país estranho sem família e sem marido. Se, inegavelmente, algumas me admiravam por isso e me viam como um exemplo de independência a ser seguido, outras tantas não compreendiam o que 
levava uma mulher a abrir mão de sua vida pessoal pelo trabalho e a escolher ter filhos tão tarde. Essa posição ambivalente, portanto, era válida para mim e também para elas. Foi deste lugar de constante negociação, portanto, que produzi dados e passei a construir meu objeto de pesquisa, uma experiência que passo a descrever no próximo tópico.

\section{Construindo um objeto de pesquisa}

A opção por acompanhar a religião vivida por jovens crentes em seus movimentos na cidade e pela cidade (MAGNANI, 2003) me impôs como dificuldade não conseguir delimitar muito bem o recorte da pesquisa durante o campo, mas apenas ao longo do processo de textualização da tese de doutorado. Como organizo pensamentos, memórias e sensações enquanto escrevo, sem muitos esquemas ou rascunhos prévios, sabia que o objeto se delinearia aos poucos, acompanhando o ritmo da escrita, embora eu não soubesse muito bem quando isso aconteceria.

Se, por um lado, a complexidade do campo embaçava a imagem daquilo que eu viria a fazer depois, por outro, eu sempre tive em mente aquilo que não queria fazer, neste caso, reificar oposições e definir o que era a IURD em Moçambique como algo estático e verticalmente definido. Sabia, também, que a religiosidade iurdiana não poderia ser pensada apenas a partir do espaço físico da igreja, o templo, mas em relação a ele. Essas certezas, também vale dizer, eram as únicas que eu carregava comigo desde que saí do Brasil e foram importantes para direcionar o meu olhar. Enquanto estive em campo, tinha em mente o texto em que Menezes (2009) discute a abordagem caleidoscópica de Robert Hertz na festa de São Besso e tentei colocar em prática um olhar atento que conseguisse observar o mesmo acontecimento por vários ângulos e a partir de diferentes escalas. Exatamente como num caleidoscópio, os eventos e situações poderiam assumir diferentes configurações que deveriam ser consideradas em suas especificidades, de modo a não "transformar a análise num somatório de ideias, mas rearticulá-las numa sobreposição de interpretações" (MENEZES, 2009: 9). Por isso, ainda que envolta por milhares de questões, eu voltei de Maputo com alguma ideia sobre como organizaria o campo posteriormente. Eu esperava, antes de tudo, escrever um trabalho sobre uma religiosidade que despertava um sentido de pertencimento e definia como ideais um conjunto de valores morais que era apropriado e mobilizado por seus membros de diferentes maneiras e em diferentes espaços da vida social. Em outras palavras, não me interessava o substantivo, a igreja, mas o verbo, a IURD em ação, uma escolha que me obrigou a procurar métodos para circunscrever esse movimento.

Para isso, decidi, em primeiro lugar, assumir analiticamente que a IURD não era um dado, isto, é, não existia a priori, mas era algo em constante construção e cuja existência variava conforme o contexto e o compromisso de seus membros. Por isso acompanhar as atividades cotidianas da membresia e conversar sobre assuntos aleatórios se tornou a mais importante das minhas tarefas. Assumir esse posicionamento, contudo, não implicava negar a existência do "poder tutelar" existente naquilo que Mafra, Swatowiski e Sampaio (2012) chamaram de "projeto pastoral de Edir Macedo", muito menos as múltiplas dimensões de poder que atravessam a relação entre fiéis e hierarquia da igreja, e até mesmo entre fiéis e fiéis (REIS, 2018). Num primeiro momento, inclusive, cheguei a enquadrar a relação entre os jovens da FJU e a IURD a partir de uma perspectiva foucaultiana tal como apresentada em a História da Sexualidade (1985), isto é, procurando 
enxergar os processos de disciplinamento de corpos, as técnicas de cuidado de si, de construção de subjetividades, de individualização e de produção de saber-poder. No entanto, olhar mais atentamente para os dados de campo, já na fase de escrita, me fez optar por centralizar a análise nas práticas dos sujeitos. Ainda que muitas dessas práticas estivessem ancoradas nas relações dos crentes com esses dispositivos de poder, me interessava, sobretudo, entender como tudo isso era mobilizado nas diferentes experiências cotidianas em casa e na rua. Dessa forma, eu poderia desvelar como os crentes viviam, negociavam, reinventavam e disputavam isso que chamamos de "religião", no interior de um grupo que era percebido por eles como uma família e cujo objetivo era promover transformações efetivas sobre si e sobre o mundo.

\section{Religião e seus públicos: os desafios de pesquisar os movimentos}

Como não poderia deixar de ser, a buscar por apreender esse movimento, estando eu mesma em movimento junto com as fiéis, me obrigou a fazer novos deslocamentos e a me confrontar com mais algumas certezas. Um dia estava a caminho do Cenáculo num táxi quando, ao informar meu destino ao motorista, fui surpreendida com uma declaração espontânea de sua parte. Para ele, a IURD seria uma boa igreja porque, em suas palavras, "depois que os jovens descobriram Deus ficaram menos confusos ${ }^{15}$ ". Ainda sem entender o sentido da frase, perguntei se os jovens não conheciam Deus ou não conheciam a Universal. O motorista foi mais claro desta vez: "não conheciam Deus". E completou dizendo que "depois que aprenderam que não é bom ficar aí a beber, fumar suruma ${ }^{16}$ e a jogar conversa fora, estavam mais responsáveis”.

Naquele momento me dei conta de que a observação do motorista - um nãocrente, como fez questão de afirmar - apontava para uma questão muito básica. "Conhecer Deus", naquele contexto, não era uma metáfora, uma forma de dizer que os jovens se converteram à Universal, mas uma referência direta à expansão do cristianismo enquanto base moral de uma sociedade. Embora tenha sido colonizada por portugueses e tido o catolicismo como religião oficial, principalmente após a ocupação que se efetivou com o Tratado de Berlim ${ }^{17}$, a atuação das missões protestantes e das lideranças dos grandes Estados Negros foram fundamentais para o processo de desenvolvimento da consciência política dos negros moçambicanos (CRUZ E SILVA, 2001; HEGELSSON, 1994; CABAÇO, 2009; REIS, 2018).

Uma das consequências diretas desses influências pode ser identificada na multiplicação das chamadas "igrejas independentes africanas"18, iniciada já na segunda década do século XX, e que se caracterizam, entre outras coisas, por leituras particulares do cristianismo que incorporam de diferentes formas as tradições africanas e a relação com os espíritos ancestrais.

\footnotetext{
${ }^{15}$ A palavra confuso, como adjetivo, era comumente empregada no sentido de baderna, confusão. Uma pessoa confusa era alguém que gostava de arranjar confusão.

16 Como se chama maconha em Mocambique.

${ }_{17}$ A Conferência de Berlim tem sido considerada por muitos historiadores como o início de um novo período histórico para o continente africano, marcado pelo domínio colonial. Tratou-se de uma reunião diplomática (com a participação de França, Grã-Bretanha, Portugal, Alemanha, Bélgica, Itália, Espanha, Áustria-Hungria, Países Baixos, Dinamarca, Rússia, Suécia, Turquia e EUA) que estabeleceu as condições básicas para estes Estados reclamarem determinadas regiões africanas como estando sob sua influência. Diversas são as interpretações sobre as causas e formas através das quais o continente passou ao controle político europeu no final do século XIX. Para uma apresentação inicial destas, ver: Uzoigwe, Godfrey N. "Partilha europeia e conquista da África: apanhado geral" in: ADU BOAHEN, Albert (ed.), História Geral da África vol. VII: a África sob dominação colonial 188o-1935. Brasília: UNESCO, 2010.

${ }^{18}$ Sobre o tema e as críticas ao conceito, ver Meyer, 2004.
} 
Após a guerra de independência ${ }^{19}$, a orientação marxista-leninista assumida oficialmente pela Frelimo, em 1977, acentuou uma postura antirreligiosa e as igrejas passaram a ser acusadas de promover a divisão entre os moçambicanos e proibidas de realizar atividades públicas. A despeito de sua postura contrária ao colonialismo português, mesmo as igrejas protestantes encontraram dificuldades para organização de atividades religiosas neste período, uma realidade que só começou a mudar em meados da década de 1980.

Com o fim da guerra civil, em 1992, o número de igrejas registrado no Departamento de Assuntos Religiosos do Ministério da Justiça de Moçambique seguiu uma linha ascendente, passando de 112 em 1992 para 907 no ano de 2017. De acordo com os dados do Censo de 2017, a população do país se divide entre católicos (27.2\%), evangélicos (15.3\%), muçulmanos (18,9\%), zione (15.6\%) e sem religião (13,9\%), incluindo ateus ou agnósticos. O cenário na cidade de Maputo, no entanto, não segue os índices nacionais, com cerca de $29 \%$ da população declarando-se evangélica, ultrapassando católicos, muçulmanos e zione. Estamos falando, portanto, de um país bastante diverso no que diz respeito à pluralidade religiosa, sobretudo quando pensamos este dado em relação ao Brasil majoritariamente cristão, e marcado por processos coloniais e pós-coloniais bastante diferentes dos nossos.

Embora seu registro oficial tenha sido feito em 13 de julho de 1993 (CRUZ E SILVA, 2003: 111), a IURD chegou a Moçambique em 1992, mesmo ano em que iniciou seus trabalhos na África do Sul (VAN WYK, 2014) e um ano depois de ter aportado em Angola (Sampaio, 2014). Atualmente, Moçambique é um dos países com o maior número de adeptos em África ${ }^{20}$ e tem sua dinâmica definida por padrões hierárquicos, campanhas e, sobretudo, por um fluxo de pessoas que conecta a IURD mundo afora, mas que está ancorada no Brasil. Assim, se a configuração do campo religioso brasileiro e o lugar ocupado pela IURD globalmente me levaram até Maputo, percebi, naquele táxi, que ter o Brasil cristão como contexto de referência me fez naturalizar a presença pública do cristianismo em Moçambique e me fez perceber a urgência desse estranhamento.

Num trabalho etnográfico, apontar as ambivalências constitutivas do campo escorregando minimamente em seus próprios juízos de valor é, ou deveria ser, uma preocupação cara a todo antropólogo. Neste caso, especificamente, eu me dei conta de que deveria ser cuidadosa para não transportar automaticamente para o contexto moçambicano as controvérsias protagonizadas pela IURD no Brasil, ou, em outras palavras, ter o olhar direcionado pelas especificidades do "campo religioso brasileiro". A melhor forma de fazer isso, sem dúvidas, era mergulhando de cabeça no universo da IURD em Moçambique, embora eu não soubesse de antemão aonde isso me levaria. Já no primeiro culto, fui seduzida pelas coreografias e pela empolgação das músicas cantadas efusivamente em changana ${ }^{21}$ para, em seguida, me impressionar com a intensidade e quantidade dos exorcismos realizados no altar. Aos poucos, fui desvelando a relação entre a IURD e a Frelimo, entendendo o contexto histórico e as controvérsias em torno da imensa visibilidade conquistada pela IURD em Moçambique.

\footnotetext{
19 O Acordo de Lusaka que estabeleceu um governo transitório foi assinado em 7 de setembro de 1974 e prepararia para que Samora Machel assumisse a presidência da República em 1975.

${ }_{20}$ Para informações sobre Igreja Universal na África Austral, ver Freston (2005).

${ }^{21} \mathrm{O}$ site oficial do governo reconhece 20 línguas nacionais, mas esse número é controverso. O português é a língua oficial. Disponível em <http://www.portaldogoverno.gov.mz/>. Acessado em 02.12.2017. De acordo com o Censo de 2007, apenas $42,9 \%$ da população da cidade de Maputo fala português. O xichangana é falado por $31,5 \%$ e xirhonga por \% $9,7 \%$. Entre os mais jovens (5-19 anos), o português é falado por 58,4\% da população. O zulu é uma das onze línguas oficias da África do Sul, onde a IURD também tem grande penetração, mas também há falantes de zulu em Moçambique, de modo que também é reconhecida como uma língua nacional no país. Na IURD, os cânticos de louvor eram todos cantados em língua local, enquanto os de adoração em português brasileiro. Sobre isso, cf. Reis, 2018.
} 
No entanto, a ausência inicial de conflito em relação à forma como eu experimentaria subjetivamente a religiosidade iurdiana dentro dos templos desapareceu na mesma velocidade em que meu movimento com os crentes se espraiava para além dos muros da igreja: muito rapidamente. Não foram raras as vezes em que me peguei completamente constrangida por sentir que estaria cooperando, ainda que infimamente, para aumentar a visibilidade da IURD quando participava de suas intervenções no mundo em forma de ações sociais contra drogas, violência, desemprego, ou, ainda, dos projetos de evangelização nas periferias da cidade, por exemplo.

Esse constrangimento pessoal, claramente assentado em meus próprios posicionamentos políticos, se chocava com a postura antropológica que eu havia decidido assumir quando entrei em campo, escancarando para mim mesma as ambivalências de pesquisar esse "outro". Ironicamente, o próprio campo se encarregou de demonstrar que minha postura compreensiva encontrava uma dupla barreira, a primeira no plano subjetivo, mas também a partir de uma condição objetiva, pois aquele corpo não-negro, mais clarinho, denunciava que eu era diferente dos outros e despertava entre os não-membros uma imensa curiosidade em torno da minha presença. Ainda que a atuação de missionários brasileiros em Moçambique não seja exatamente uma novidade, entrar em contato com um deles causava um grande alvoroço entre adultos, jovens e, principalmente, crianças fascinadas com o meu cabelo que "caía" e poderia ser tão facilmente trançado. De certa forma, eu me sentia legitimando o projeto social, moral e nacional da IURD para aquelas pessoas e aquilo me causava incômodo.

Se, por um lado, meu receio era justamente produzir uma análise que refletisse concepções engessadas sobre religião e espaço público, assim, como se fossem opostos, quando inúmeros trabalhos já apontam para a presença pública da religião e os limites do paradigma do secularismo (CASANOVA, 1994; HANSEN, 2014, MONTERO, 2016), por outro, o meu constrangimento ao acompanhar as ações públicas da igreja revelavam para mim, mais uma vez, as ambivalências dessa relativização. Por que, afinal de contas, era um problema que a igreja estivesse na rua, na mídia de massa ou na política? Dado o contexto sociopolítico e a relação entre a Frelimo e a IURD, a partir de onde eu deveria observar tudo isso?

Diante desse terreno escorregadio, onde domínios que aparentemente estariam separados se misturam, procurei pensar esse emaranhado complexo que envolvia fiéis, não-fiéis, igreja, rua, mídia, partido e Estado a partir da apropriação que Meyer e Moods (2006) fazem do conceito de "esfera pública". Sem encampar por completo o conceito habermasiano, nem tomar a noção de esfera pública como universal, ele se mostra, de acordo com as autoras, uma ferramenta útil para pensar o contexto pós-colonial se utilizado "como ponto de partida para o desenvolvimento de uma moldura mais adequada para análise das complicadas políticas de identidade na era da informação" (2006: 4, tradução minha). Na concepção das autoras, essa ideia de esfera pública pode ser útil para entender a emergência de novas arenas de debate que, embora não ligadas diretamente ao Estado-Nação, engendram ideias e sentimentos compartilhados entre pessoas de quadros cultural ou étnico distintos. Em outras palavras, despertam um pertencimento comum e, consequentemente, formas convergentes de estar e intervir no mundo.

Em Maputo, fiéis atestavam os benefícios proporcionados pela adesão à IURD em suas performances cotidianas junto a não-crentes, mas toda essa informação também podia ser acessada, sempre que possível, pelos poderosos meios de comunicação de massa dominados pela IURD como o jornal impresso, a rede 
de televisão e a rádio próprios. Assim, os crentes assistiam novelas que retratavam histórias bíblicas produzidas pela brasileira Rede Record, liam livros religiosos e de autoajuda escritos pela família Macedo, circulavam pela cidade levando consigo a Folha Universal para distribuir nos bairros, montavam palcos com microfones e caixas de som em praças públicas para emissão de discursos religiosos que reivindicavam um país melhor, podiam comprar CDs de músicas religiosas em changana e zulu vendidos nas igrejas a preços acessíveis e estabelecer contato via WhatsApp com obreiros ou grupos sempre disponíveis a ajudar. Tudo isso me fez perceber que a sociabilidade engendrada a partir das práticas cotidianas dos crentes não vinculava necessariamente a religiosidade iurdiana ao espaço físico do templo, mas que era capaz de produzir um forte sentido de pertencimento. Se, como afirma Stolow, a religião "está entrelaçada a objetos, técnicas e instrumentos do mundo material no seio do qual os atores e as ações religiosas são incorporados e com base no qual ideias, experiências práticas e modos de associação religiosos se tornam possíveis" (2014: 152), eu acrescentaria que, essas ideias, experiências e modos de associação fazem parte de um movimento que faz a "religião" circular, transmutar-se e forjar sensibilidades que promovem transformações efetivas na arena pública.

Estes mesmos jovens, entretanto, também precisam se virar, se proteger e sobreviver na cidade em meio a altos índices de desemprego, pobreza extrema e os ecos das inúmeras guerras pelas quais o país passou em sua história recente. Com isso, quero dizer que, para além da igreja, o meio urbano e semiurbano no qual esses jovens circulavam diariamente não deveriam ser percebidos como inertes, mas considerados como espaços produtores de sociabilidades, padrões de troca e rituais da vida pública (MAGNANI, 2002: 6). Assim, se, por um lado, o conceito de "religião vivida" se mostrou uma ferramenta útil para apreender a religião tal como as pessoas a vivem e sua relação com as dimensões materiais da própria religião, por outro, eu ainda me sentia profundamente incomodada por definir, de antemão, como religião, aquilo que os crentes faziam. Definitivamente não era só isso.

Se, como nos lembra Jeremy Stolow, a própria categoria religião está sempre sendo repensada (2014: 149), defini-la a priori não parecia uma estratégia coerente com o trabalho que eu me dispunha a fazer. Ao mesmo tempo, minha pesquisa se debruçava sobre as ações de membros de um grupo que se definia como religioso, embora nem sempre as ações que observei em campo fossem necessariamente religiosas, revelando a boa e velha tensão entre categoria nativa e categoria analítica tão cara aos antropólogos. Para resolver mais este impasse, decidi que a tentativa de não essencializar a religião (e pensar os meus constrangimentos) exigiria que eu articulasse outras perspectivas teóricas ao conceito de religião vivida, tais como performances e cultura material, por exemplo. Não se tratava, contudo, de não levar a sério a essencialização que os próprios crentes faziam de si mesmos - percebo-os como crentes da Universal, assim como eles se definem - apenas me afasto dela para tentar apreender os efeitos que essa essencialização produz no mundo, inclusive, quando se escreve e quando se fala sobre ela. No fim das contas, essa foi a saída que encontrei para dar conta das questões colocadas pelas ambivalências sobre a presença pública dos fiéis - e a minha própria - na cidade e me permitiu construir com mais clareza um objeto de pesquisa. 


\section{O trabalho de escrever}

Neste artigo, procurei aprofundar algumas questões que emergiram da experiência etnográfica que resultou na tese de doutorado (REIS, 2018) sobre a "religião vivida" por "membros-engajados" da IURD em Maputo. Por isso, além de recompor a estrutura da IURD em Maputo, a tese também analisou a interação entre os membros na igreja, em casa e na rua, sua relação com as diferentes tecnologias na mediação com o divino, incluindo o dinheiro, e com as moralidades instituídas pela igreja. Tudo isso me permitiu detalhar os meandros de uma religiosidade que, em intensa relação com o partido governante, produz um forte sentido de pertencimento e aglutina os jovens em torno de uma comunidade específica, a Família Universal de Moçambique. Ao final, defendi que o engajamento desses sujeitos na religiosidade iurdiana era fundamental para que a IURD pudesse existir e se expandir física e simbolicamente, a ponto de ter se transformado num ator político importante na esfera pública moçambicana.

No entanto, até que eu conseguisse definir minimamente qual seria meu objeto de estudo, um longo caminho foi percorrido, muitos imprevistos enfrentados e nem todos solucionados, como ficou bem demonstrado nos tópicos anteriores. $\mathrm{E}$, ao contrário do que se possa imaginar, muitas dessas questões não foram percebidas por mim na medida em que aconteciam, mas apenas durante o trabalho da escrita. Se, como nos ensina Cardoso de Oliveira (2006), o trabalho do antropólogo é olhar, ouvir e escrever - e aqui acrescentaria, ainda, cheirar, sentir e tocar - é muito comum que os debates clássicos sobre metodologias de pesquisa deem mais atenção aos dois primeiros que ao trabalho de textualização. Evidentemente, não se trata de ignorar clássicos como $A$ Escrita da Cultura, organizado por Clifford e Marcus (2016), toda a reflexão de Geertz (1989) e até mesmo discussões mais contemporâneas como aquelas feita por Ingold (2013), mas de dar visibilidade aos obstáculos e desdobramentos do processo de textualização.

Para realização de um bom trabalho, nós, antropólogos, precisamos realizar um levantamento bibliográfico que se multiplica a cada nova referência cruzada, mergulhamos no trabalho etnográfico trazendo na bagagem experiências que nem sempre conseguimos racionalizar ou pensar sobre, compartilhamos nossas ideias com colegas, participamos de congressos, classificamos o material recolhido em campo. Ao final, toda essa experiência precisa ser comprimida num texto, a meu ver, a parte mais difícil de todas. E não me refiro apenas às dificuldades que envolvem o trabalho de descrever/interpretar/inventar aquilo que nos dispusemos a pesquisar, mas, sobretudo, à dura realidade trazida pelo momento de textualização de que muitas ideias não serão passíveis de desenvolvimento, tal como nos alerta Menezes (2004: 52). Nesse sentido, corroboro o argumento de Oliveira de que é impossível dissociar o pensar do escrever porque "é no processo de redação de um texto que nosso pensamento caminha, encontrando soluções que dificilmente aparecerão antes da textualização dos dados provenientes da observação sistemática" (2006: 32).

Assim, na mesma medida em que apresenta soluções, o trabalho de escrever desvela um infindável conjunto de questões sobre as quais nunca havíamos pensado antes e que deverão necessariamente ser solucionadas ou descartadas, mesmo que temporariamente, para que a etnografia se autonomize e ganhe vida própria no mundo. Não por acaso, escrever revelou-se, para mim, uma experiência intrinsecamente conectada ao trabalho de campo, sobretudo na medida em que eu conseguia reviver quase que integralmente as situações experimentadas anos antes, incluindo odores, arrepios e emoções. Como disse antes, muitas das 
questões que se tornaram problemas centrais na minha tese não foram percebidos durante o campo, mas alguns anos depois, quando precisei resgatar memórias, insights, anotações e áudios para escrever sobre eles. E, para isso, o trabalho de tempo foi fundamental.

\section{Dar tempo ao tempo: uma parada necessária}

Volto, agora, ao problema inicial deste texto. Se, como demonstrei até aqui, perseguir o movimento se tornou quase uma obsessão etnográfica, termino o texto invocando a importância do movimento oposto: a pausa. O trabalho do tempo, às vezes inimigo da pesquisa, mostrou-se fundamental para que eu percebesse que não faria uma etnografia sobre alguma coisa, mas da relação estabelecida entre mim e aquilo que se delineou aos poucos como meu objeto de pesquisa. Da mesma forma, também foi o distanciamento do campo que me fez perceber a urgência de abandonar algumas ideias e decidir, finalmente, que não escreveria especificamente sobre religião, nem sobre espaço público, nem sobre relações de poder. Não me guiaria por conceitos que me imobilizassem sendo mais prescritivos que descritivos, mas pelo fluxo de coisas e pessoas que a todo momento refaziam suas trajetórias e sentidos no interior de uma religiosidade específica, a fim de perceber como esse emaranhado se configurava ao final. Em resumo, toda minha percepção sobre a IURD em Maputo foi compreendida e apresentada a partir da minha relação com membros da FJU, da forma como eu me relacionei com eles e, principalmente, eles comigo.

Para além disso, também quis chamar atenção para o fato de que os diferentes estágios da pesquisa não formam, definitivamente, um processo linear. Trabalho de campo, construção do objeto e textualização, como demonstrei neste texto, são etapas de trabalho que se interpelam a todo o tempo e exigem de nós uma constante ressignificação. Não por acaso, eu invoco flashes de cada uma dessas etapas em todos os tópicos, a fim de demonstrar como elas se atravessam, complementam e se desordenam quando necessário. Nesse meio de campo, os conceitos aparecem como ferramentas indispensáveis, menos para explicar e circunscrever a análise e mais para ajudar a experimentar saídas para os problemas colocados pelo campo.

Em síntese, esse esforço de tentar conferir alguma inteligibilidade a um processo que ainda hoje se reflete no meu trabalho, apontando suas especificidades - as minhas e a do campo em um país africano - tem como finalidade destacar a importância desses deslocamentos para o fazer etnográfico, sobretudo quando eles nos movem tão subitamente dos lugares onde nos acostumamos a (ou lutamos para) estar. Durante todo o tempo, oscilei entre ser uma negra não crente e uma branca semi-crente experimentando temporalidades, festas, ações, interações, materialidades e política a partir da convivência com os jovens da FJU. As ambivalências constitutivas do campo, mais que um problema, se apresentaram, ao final, como uma solução. Melhor que definir qualquer coisa é demonstrar suas várias combinações possíveis, mas isso eu só descobri dando tempo ao tempo, parada, já no Brasil, escrevendo sobre como faria uma etnografia do movimento de jovens crentes pela cidade de Maputo. 


\section{Referências}

BLANES, Ruy Llera. The atheist anthropologist: believers and non-believers in anthropologial filedwork. Social Anthropology, 2006 (14): 223-234.

CAMPOS, Leonildo Silveira. Teatro, templo e mercado: organizaçãoo e marketing de um empreendimento neopentecostal. Petrópolis: Vozes; São Bernardo do Campo: Universidade Metodista de São Paulo, 1997.

CARDOSO DE OLIVEIRA, Roberto. "O trabalho do antropólogo: olhar, ouvir, escrever”. In: O trabalho do antropólogo. São Paulo: Editora Unesp, 2006. pp. 1736.

CASANOVA, José. Public religion in the Modern World. Chicago: The University of Chicago Press, 1994.

CLIFFORD, James. "Introdução: verdades parciais". In: CLIFFORD, James; MARCUS, Geroge (orgs.). A escrita da cultura: poética e política da etnografia. Rio de Janeiro: Ed. UERJ; Papéis Selvagens Edições, 2016. pp. 31-62.

CLIFFORD, James; MARCUS, Geroge (orgs.). A escrita da cultura: poética e política da etnografia. Rio de Janeiro: Ed. UERJ; Papéis Selvagens Edições, 2016.

COLEMAN, Simon. "Zonas Fronteiriças: ética, etnografia e o cristianismo "repugnante". Debates do Ner, 1 (33): 271-312, 2018.

CRUZ E SILVA, Teresa. Igreja Universal em Moçambique. In: ORO, Ari Pedro, CORTEN, André, DOZON, Jean-Pierre (org). Igreja Universal do Reino de Deus: os novos conquistadores da fé. São Paulo: Paulinas, 2003. pp. 123-135.

FOUCAULT, Michel. História da Sexualidade III: o cuidado de si. Rio de Janeiro: Graal, 1985.

FRESTON, Paul. The Universal Church of the Kingdom of God: a brazilian church finds success in Southern Africa. Journal of Religion in Africa, 35 (1): 33-65, 2005 .

GIUMBELLI, Emerson. Símbolos Religiosos em controvérsias. São Paulo: Terceiro Nome, 2014.

GIUMBELLI, Emerson. O Fim da religião: dilemas da liberdade religiosa no Brasil e na França. São Paulo: Attar/PRONEX, 2002.

GEERTZ, Clifford. Works and Lives: Anthropologist as author. Stanford: Stanford University Press, 1989.

GOLDMAN, Marcio. Os Tambores dos Mortos e os Tambores dos Vivos. Etnografia, Antropologia e Política em Ilhéus, Bahia. Revista de Antropologia, 46 (2): 445-476, 2004.

GOMES, Edilaine Campo. A Era das Catedrais: a autenticidade em exibição. Rio de Janeiro: Garamond, 2011.

HALL, David. Lived Religion in America: Toward a History of Practice. Pinceton, Princeton University Press, 1997.

HANSEN, Thomas B. "Religion". In: NONINI, Donald. A Companion to Urban Anthropology. London: Willey: Blackwell, 2014. pp. 364-380. 
HARDING, Susan. "Representing fundamentalism: the problem of the repugnant cultural other”. Social Research, 58 (2): 373-393, 1991.

HARTEL, Heather A. Producing Father Baker: material and visual practices of making a saint. Material Religion, 2(3): 320-349, 2006.

HELGESSON, A. Church, State and people in Mozambique: an historical study with special enphasis on Methodist developments in Inhambane Region. Uppsala: Swedish Institute of Missionary Research, 1994.

INGOLD, Tim. "Repensando o animado, reanimando o pensamento". Revista Espaço Ameríndio, 7(2): 10-25, 2013.

KAMP, Linda Van de. Violent conversion: Brasilian pentecostalism and the urban pioneering of women in Mozambique. Rochester: James Currey, 2016.

MAFRA, Clara; SWATOWISKI, Claudia; SAMPAIO, Camila. O projeto pastoral de Edir Macedo: uma igreja benevolente para indivíduos ambiciosos? Revista Brasileira de Ciências Sociais, 27 (78): 81-96, 2012.

MAGNANI, José Guilherme. De perto e de dentro. Notas para uma etnografia urbana. Rev. Bras. Ci. Soc., São Paulo, 17 (49): 11-29, 2002.

MARIANO, Ricardo. Neopentecostais: sociologia do novo pentecostalismo no Brasil. $2^{\text {a }}$ edição. São Paulo: Loyola, 2005.

MARIZ, Cecília Loreto. Perspectivas sociológicas sobre o pentecostalismo e o neopentecostalismo. Revista de Cultura Teológica, 3: 37-52, 1995.

MARIZ, Cecília Loreto; CAMPOS, Roberta. Pentecostalism and 'National Culture': a dialogue between brazilian social sciences and the anthropology of christianity. Religion and Society: advances in research, 2: 106-121, 2011

MENEZES, Renata de Castro. A dinâmica do sagrado: rituais, sociabilidade e santidade num convento do Rio de Janeiro. Rio de Janeiro: Relume Dumará: Núcleo de Antropologia da Política/UFRJ, 2004.

MENEZES, Renata de Castro. Revisitando Saint Besse - Ou, o que Robert Hertz e a Escola Francesa de Sociologia ainda têm a nos dizer sobre festa". Religião $e$ Sociedade, 29 (1): 179-199, 2009.

MEYER, Birgit. Christianity in Africa: from African Independent to Pentecostal Charismatic Churches. African Review of Anthropology, 33: 447-74, 2004.

MEYER, Birgit; MOODS, Annelies (org). Religion, Media and Public Sphere. Bloomington and Indianapolis: Indiana University Press, 2006.

MONTERO, Paula. "Religiões Públicas” ou religiões na Esfera Pública? Para uma crítica ao conceito de campo religioso de Pierre Bourdieu”. Religião e Sociedade, 36 (1): 128-150, 2016.

NADER, Laura. “Up the Anthropologist: Perspectives Gained from 'studying up". In: HYMS, D. (ed.) Reinventing Anthropology. New York: Random Hous, 1969. pp. 284-311.

ORTNER, Sherry. Poder e Projetos: "Reflexões sobre agência”. In: GROSSI, Pilar; ECKERT, Cornelia; FRY, Peter. Conferências e diálogos: saberes e práticas antropológicas. Nova Letra Gráfica e editora. 2007. 
PIERUCCI, A.F. "Interesses religiosos dos sociólogos da religião". In: ORO, Ari Pedro; STEIL, Carlos Alberto (org.). Globalização e religião. Petrópolis: Vozes, 1997.

REIS, Lívia. Ser Universal: crentes engajados e práticas cotidianas na cidade de Maputo. Rio de Janeiro, tese de doutorado, Universidade do Estado do Rio de Janeiro, 2018.

REIS, Lívia. Estreitando alianças, criando crentes moçambicanos: notas sobre a cooperação entre a Igreja Universal do Reino de Deus e a Frelimo na cidade de Maputo. Revista De Antropologia, 62 (3): 584-609, 2019.

RIOS, Flavia. “O que o colorismo diz sobre as relações raciais brasileiras?”, 2019. [online]. Disponível em: <https://www.geledes.org.br/o-que-o-colorismo-dizsobre-as-relacoes-raciais-brasileiras/>. Acessado em 20.05.2020.

SAMPAIO, Camila. Através e apesar da "Reconstrução Nacional" em Angola: circunstâncias e arranjos nos limites da vida. Rio de Janeiro, tese de doutorado, Universidade do Estado do Rio de Janeiro, 2014.

SCHECHNER, Richard. "What is performance?". In: Performance Studies: An introduccion. Second edition. New York \& London: Routledge, 2006. pp. 28-51.

STOLLOW, Jeremy. Religião e Mídia: notas sobre pesquisas e direções futuras para um estudo interdisciplinar. Religião \& Sociedade, 34 (2): 146-160, 2014.

THOMAZ, Omar Ribeiro. “Contextos cosmopolitas: missões católicas, burocracia colonial e a formação de Moçambique (notas de uma pesquisa em curso)". In: Estudos Moçambicanos. Maputo: Centro de Estudos Africanos, 2001.

THOMAZ, Omar Ribeiro. "Escravos sem dono": a experiência social dos campos de trabalho em Moçambique no período socialista. Revista de Antropologia, 51 (1): 177-214, 2008.

UZOIGWE, Godfrey N. "Partilha europeia e conquista da África: apanhado geral". In: ADU BOAHEN, Albert (ed.), História Geral da África vol. VII: a África sob dominação colonial 1880-1935. Brasília: UNESCO, 2010.

VAN WYK, Ilana. The Universal Church of the Kingdom of God in South Africa: a church of strangers. Cambridge: Cambridge University Press, 2014.

WACQUANT, Loïc. Corpo e Alma Notas Etnográficas de um Aprendiz de Boxe. Rio de Janeiro: Relume Dumará, 2002. 